\title{
Role amerických a francouzských spolupracovníků v mezinárodní strategii redakčního týmu Sociologické revue ve 30 . letech ${ }^{1}$
}

\author{
The Role of Foreign Contributors from France and the United States \\ in the International Strategy of the Czech Periodical Sociologická \\ Revue and Its Redacting Team in the 1930s
}

Christopher Montel

\begin{abstract}
Three French sociologists (Bouglé, Duprat and Richard), as well as three sociologists from the United States (Hasek, Rouček and Sorokin), exclusively represented Western sociology in a list of nine foreign collaborators, which featured from 1933 to 1940 on the first page of the Czech periodical Sociologická revue. Duprat and Richard were evidently included in this list at a time when the Masaryk Sociological Society, whose publishing organ was the Sociologická revue, played a significant role in the resumed activities of the International Institute of Sociology. The collaboration of the three "American" sociologists was more participative. It answered the urgent need, according to the revue's redacting team, to inform readers on the latest developments in the field from America. The names of Bougle, and above all Sorokin, undoubtedly represented in this list a symbolic advantage for the revue's redacting team and its international strategy.
\end{abstract}

KEY WORDS Internationalisation of sociology, International Institute of Sociology, The Czech periodical Sociologická revue

\section{Úvod}

Podrobné analýzy celkové struktury Sociologické revue (SR) byly již dříve publikovány Zdeňkem Nešporem (2007) a Dušanem Janákem (2011). Cílem této studie je zaměřit se na to, co můžeme nazývat mezinárodní strategií redakce časopisu $S R$ ve vztahu k západní sociologii. Internacionalizace české sociologie byla již součástí Benešovy výzvy, která byla zahrnuta do veřejného dopisu Bláhovi publikovaného jako úvodní příspěvek prvního vydání $S R$ v r. 1930. Úkolem podle ministra zahraničních věcí Edvarda Beneše bylo „,...] zapojovati československou práci sociologickou v rozsahu naznačeném do světové práce v tomto oboru. Nejen informovati, což je samozřejmé, o světové práci sociologické, ale i informovati cizinu

Sociální studia / Social Studies SPEC/2020. S. 53-68. ISSN 1214-813X.

1 Srdečně děkuji Dušanu Janákovi za jeho neocenitelnou pomoc a rady. Také děkuji kolegyni Lucii Felcan Rajlové, která částečně jazykově upravila můj článek, za její laskavost a trpělivost. 
o československé práci sociologické na tomto širším základě“ (Beneš 1930: 4). Zaměříme se na to, jak byla internacionalizace uskutečněna prostřednictvím oficiální spolupráce se západními zahraničními sociology uváděnými v seznamu zahraničních spolupracovníků revue.

Francouzští a američtí sociologičtí zástupci převládali na seznamu devíti zahraničních spolupracovníků, který byl publikován na první straně revue od r. 1933. Kromě jmen třech slovanských sociologů (V. Ganev z Bulharska, Srb Mirko Kosić a Chorvat Mijo Mirković z Jugoslávie) byla sociologie ze Západu zastoupena třemi francouzskými sociology (Célestin Bouglé, Guillaume Léonce Duprat ze Ženevy² a Gaston Richard) a v čísle 2-3 (1933) také dvojicí sociologů působících v USA (ruský exulant Pitirim Sorokin a Čech Josef Rouček). Západní země se solidní sociologickou tradicí jako Itálie nebo Belgie nebyly naopak v tomto seznamu zastoupené vůbec. Př́pad Německa je ještě překvapivější s ohledem na absenci známých osobností, jako je německo-italský sociolog Robert Michels, který byl v kontaktu např. s Bláhou a jehož články byly publikovány v $S R$. Překvapivá je tato absence také s ohledem na významnou, ovšem sporadickou publikační účast německy mluvících spolupracovníků (mimo Československo) v $S R$, jakož i na počet recenzí děl publikovaných v němčině. ${ }^{3} \mathrm{~V}$ následujícím čísle (4. svazek, r. 1933) bylo přidáno jméno třetího sociologa z USA, Američana českého původu C. W. Haseka. Seznam se nezměnil až do smrti Célestina Bouglého v r. 1940. Tento rok byl zároveň tím, kdy byla revue naposledy aktivní, než byla přinucena svou činnost přerušit z důvodu válečných událostí. Po obnovení činnosti revue mezi lety 1946 až 1949 se už na první straně žádné jméno zahraničního (ani českého) spolupracovníka vedle I. A. Bláhy neobjevilo.

Na základě rozboru článků a institucionálního i sociálního pozadí zahraničních spolupracovníků můžeme v mezinárodní činnosti $S R$ rozlišit tři hlavní typy spolupráce. První, kterou nazýváme institucionální, byla skoro výhradně podmíněna úlohou Masarykovy sociologické společnosti (MSS), jejímž orgánem byla $S R$ od konce 20. let, př̌i obnovení činností Mezinárodního sociologického ústavu (MSÚ). Pod tento typ lze zařadit spolupráci s Richardem a Dupratem. Druhým typem byla spolupráce s mezinárodně významnými vědeckými osobnostmi, kterou nazýváme spoluprací symbolickou. Sem patří spolupráce s Bouglém a Sorokinem. Roučka s Hasekem lze označit za participativní spolupracovníky, jejichž role byla především v referování o nejnovějších sociologických dílech ze Spojených států amerických. Ačkoli jejich prínos $\mathrm{k}$ obsahu revue byl po této stránce výrazný a dobově významný, $\mathrm{z}$ hlediska sociologického rozboru internacionalizace české meziválečné sociologie je v podstatě nejméně zajímavý a budeme se mu věnovat pouze ve stručnosti. V naší typologii se jedná o ideální typy (ve Weberově smyslu) vztahů. Jejich prolínání přehledně zobrazuje Tabulka 1.

2 Jména zahraničních spolupracovníků byla spárována $\mathrm{s}$ univerzitou, na které působili. Francouz Guillaume Léonce Duprat (1872-1956) byl profesorem v Ženevě od r. 1922 do r. 1939, ale někdy je mylně označován za Švýcara.

3 Tato nepríitomnost může být alespoň částečně vyložena poměrně rozšířeným zvykem české inteligence překročit germánský svět, ve kterém byla geograficky, historicky a kulturně enklávová, a odlišit se od něj. Také může být paradoxně vyložena tím, že se vedoucí tým revue mohl klidně spoléhat na německy mluvící české spolupracovníky, již mají navíc poměrně snadný přistup k dílům ze zemí s německojazyčnými nakladatelstvími včetně pobaltských států. 
Tabulka 1: Rozdělení oficiálních spolupracovníků $S R$ ze Západu dle typu spolupráce se Sociologickou revui (i Masarykovou sociologickou společností)

\begin{tabular}{|l|c|c|c|c|c|c|}
\hline & \multicolumn{3}{|c|}{ Francie } & \multicolumn{3}{c|}{ Spojené státy americké } \\
\hline $\begin{array}{c}\text { iméno } \\
\text { typ spolupráce }\end{array}$ & Richard & Duprat & $\underline{\text { Bouglé }}$ & $\underline{\text { Sorokin }}$ & $\underline{\text { Hasek }}$ & $\underline{\text { Rouček }}$ \\
\hline institucionální & ++ & ++ & $+/-$ & + & -- & -- \\
\hline participativní & -- & -- & -- & ++ & ++ & ++ \\
\hline symbolická & $+/-$ & -- & ++ & ++ & -- & -- \\
\hline
\end{tabular}

Zdroj: Typologizace je volně inspirovaná př́stupem D. Janáka (Janák 2009: 39-40; 2018: 35-95)

Tabulka 1 hodnotí zahraniční spolupracovníky v každém typu spolupráce na škále od nepatrné (- -) až po velmi významnou $(++)$. Z přehledu je patrné, že nejvýznamnějším spolupracovníkem byl Pitirim Sorokin. Níže v textu bude o každém typu pojednáno ve větším detailu. Mezinárodní aktivita redakce $S R$ vyústila v určité rozdělení práce mezi Bláhu a jeho kolegu Chalupného, které začalo od druhé poloviny 20. let. Proto je článek strukturován také dle tohoto rozdělení práce. Díky svému osobnímu vztahu s Dupratem se stal Chalupný v první polovině 30. let důležitým zástupcem české sociologie na zahraničních kongresech MSÚ (1. kapitola), zatímco Bláha se jako šéfredaktor věnoval zřejmě více obsahu časopisu (2. kapitola).

\section{Institucionální spolupráce s představiteli Mezinárodního sociologického ústavu (MSÚ)}

\section{Stručná prezentace MSÚ a počátkư jeho vztahu s českou sociologií (1894-1926)}

Spolupráce s představiteli MSÚ se od dalších dvou typů vztahů odlišovala především tím, že nebyla pouze prostředkem ,dovozu“ zahraničního ,intelektuálního zboží““ do českého sociologického prostředí, ale především nástrojem ,,vývozu“ české sociologie na Západ. Podstatnou roli v tomto procesu sehrál Emanuel Chalupný, ale počátky lze datovat ještě před vznik samostatného Československa. MSÚ byl organizací založenou v r. 1894 mladým francouzským sociologem Reném Wormsem (1869-1926). Přestože MSÚ měl být organizací mezinárodní, byl právně i co do fungování $\mathrm{v}$ podstatě francouzskou organizací. Mohli bychom rozlišovat dvě období MSÚ, tj. „Wormsovo“ období (1894-1926) a následující období „Dupratovo“ (do r. 1937). Pro naši diskusi je třeba pamatovat na dvě skutečnosti související s Wormsovým obdobím MSÚ. Za prvé, MSÚ existoval jako organizace především díky sjezdům, které pořádal. Prezentace příspěvků na těchto sjezdech účastníkům z českých zemí umožnila nejen lepší viditelnost jejich individuální práce, ale také české sociologie jako celku. Za druhé bylo členství víceméně určeno osobními konexemi Wormse. To platí např. v případě Masaryka, který od Wormse přijal jak pozvání, aby se stal členem už v roce založení ústavu, ${ }^{4}$ tak i nominaci na viceprezidenta v r. 1908 a prezidenta ročního výboru v r. 1921.

4 Masarykův ústav a archiv AV ČR Praha, dále jako MÚA AV, f. T. G. Masaryk, k. P-65, i. č. P-19-7 Worms, dopis Wormse Masarykovi z 14.8.1894. 
Př́spěvky a recenze děl českých sociologů se objevovaly v časopise MSÚ Revue internationale de sociologie (RIS) od jejího vzniku již na konci 19. století. Zásluhu na tom mělo nesporně členství T. G. Masaryka v MSÚ. V RIS byla už v r. 1898 vydána Wormsem do francouzštiny přeložená verze Masarykova článku publikovaného v témže roce v časopise Naše doba, viz Masarykovo dílo Védecká a filosofická krise současného marxismu (Masaryk 1898). Dvě jeho německy psaná díla byla recenzována v r. $1899^{5}$ a Masarykovo jméno bylo přidáno už od r. 1895 do seznamu tehdy 72 spolupracovníků, a to na první stranu RIS. Podobně tomu bylo o 38 let později u jmen dvou vedoucích MSÚ Richarda a Duprata na první straně časopisu MSS $S R$. Edvard Beneš byl během svého válečného pobytu v Paříži v kontaktu s Wormsem a také v r. 1919 přispěl do RIS, když se účastnil mírových jednání. ${ }^{6}$ Od r. 1916 byl členem Pařřžské sociologické společnosti (Rolová 2015, s. 158), společnosti také založené Wormsem. V r. 1928 byl zahrnut v seznamu členů MSÚ v AIIS, ale už v r. 1921 ho Worms oslovoval titulem náhradník ústavu. ${ }^{7}$ Tohoto roku Bláha publikoval v RIS prezentaci svého díla o současné české sociologii (Bláha 1921).

V r. 1926 nastoupil do funkce generálního tajemníka Gaston Richard (1860-1945). Jako generální tajemník měl Richard logistickou roli v obnovení činností MSÚ ve druhé polovině 20. let. Zúčastnil se prvního poválečného sjezdu v říjnu 1927 v Paříži, ${ }^{8}$ kde byly nakonec prezentovány př́spěvky dříve zaslané Wormsovi a byl ustanoven nový roční výbor a Duprat jako jeden $\mathrm{z}$ jeho viceprezidentů. $\mathrm{V}$ dopise napsaném neprodleně po sjezdu řediteli Mezinárodního institutu pro intelektuální spolupráci (MIIS) ${ }^{9}$ se Richard zmínil, že bylo rozhodnuto konat další sjezd v r. 1930 v Ženevě, na základě pozvání Ženevskou sociologickou společností (ŽSS) vedenou Dupratem. Ten se dokázal prosadit v MSÚ nejen zásluhou své energie, ale také díky tomu, že se MSÚ ocital v poměrné stagnaci. Duprat se záhy po Wormsově úmrtí stal de facto vedoucím MSÚ, řadu let před svým oficiálním dosazením do funkce generálního tajemníka v r. 1930. O tři roky později se MSÚ proměnil v Mezinárodní federaci společností a ústavů sociologických (Fédération internationale des sociétés et instituts de sociologie, MFSÚS) (Rolová 2011, s. 18, 33, 36). Rozhodující úloha obou vedoucích v obnovení MSÚ byla zdůrazňována v SR. V r. 1932 Antonín Obrdlík napsal o přípravě sjezdu MSÚ v Ženevě r. 1933: „Celý podnik je na prvém místě výsledkem a zásluhou neúnavné činnosti nynějšího předsedy Mezinárodní sociologické společnosti Gastona Richarda a ovšem jejího podivuhodně

$5 \quad$ Palacky's Idee des böhmischen Volkes a Die philosophischen und sociologischen Grundlagen des Marxismus.

6 MÚA AV, f. E. Beneš, IV/2, k. 31, sign. KOR-98; k. 44, sign. KOR-160, 8 dopisů Wormse Benešovi mezi 5. 2. 1915 a 29. 8. 1925. Podle těchto dopisů Beneš nejen konečně zaslal po opakovaných Wormsových prosbách př́spěvek redakci RIS v r. 1919, ale také přislíbil Wormsovi recenzi o „knize“ od Bláhy v r. 1916. Zmíněnou knihou zřejmě bylo jeho dílo Město: Sociologická studie.

7 MÚA AV, f. E. Beneš, IV/2, k. 31, sign. KOR-98, dopis Wormse Benešovi 21. 10. 1921.

8 Poslední sjezd Wormsova období se konal v r. 1912 v Římě. Worms zemřel před tím, než uspořádal nový sjezd (první od vypuknutí první světové války), jenž byl původně plánován na rok 1925, ale neúspěšně.

9 Archivní fond UNESCA, i. č. DD - VII - 8 - IICI, dopis Richarda řediteli MIIS z 17. 10. 1927, s. 4. MIIS byla v mnoha ohledech předchůdcem UNESCA a byla přičleněná ke Společnosti národů v Ženevě. 
čilého tajemníka G. L. Duprata“ (Obrdlík 1932: 395). Faktické Dupratovo vedení bylo natolik očividné, že byl později popsán Chalupným jako „skutečný vedoucí duch Institutu“ (Chalupný 1935: 383).

Úloha Masarykovy sociologické společnosti v obnovení činnost MSÚ: spolupráce mezi Chalupným a Dupratem

Vztahy mezi československou sociologií a MSÚ se staly těsnějšími díky osobnímu sblížení mezi Chalupným a Dupratem v polovině 20. let. Antonín Obrdlík recenzoval v r. 1931 v SR francouzskou verzi Chalupného Systému sociologie v náčrtku (Précis d'un système de sociologie). Tam cituje úryvek Dupratovy předmluvy k dílu Chalupného jako důkaz, že „leč i cizina oceňuje tuto jeho [Chalupného] dovednost“ (Obrdlík 1931: 60). Osobní spolupráce Chalupného s Dupratem začala ve skutečnosti nejpozději v lednu $1926^{10}$ (o měsíc dřive, než zemřel Worms) během jedné z Chalupného návštěv v Ženevě, ${ }^{11}$ a tak Duprat napsal předmluvu k dílu Chalupného už v r. 1927. Za tímto gestem spolupracovníka byl bezpochybně záměr podnítit Chalupného, aby se podílel na jeho projektu transformace MSÚ v MFSÚS. Ve svém dopise z 8. ř́jna 1927, který poslal společně s předmluvou, Duprat napsal: „Potěšilo by mě, kdybyste se stal členem naší Ženevské sociologické společnosti: zde [v Ženevě] se bude konat další sjezd Mezinárodního sociologického ústavu a musíme ho uspořádat. Byla by nám účast Masarykovy sociologické společnosti velmi užitečná, a Vy byste mohl být jejím zprostředkovatelem. “12

Bylo už zmíněno, že MSÚ dosud fungoval jako velmi osobně strukturovaná organizace kolem Wormse a noví členové byli zváni jednotlivě. Duprat se přihlásil ke strukturální reorganizaci MSÚ na základě federace sociologických společností už před oficiálním založením MFSÚS v r. 1933. Nyní bylo třeba, aby se členové nebo kandidáti stali nejdříve členy společností, jež byly součástí ústavu. Reforma neměla pouhý organizační cíl, ale shodovala se s Dupratovou vizí plně přičlenit MSÚ do sítě ženevských organizací a MSÚ se měl stát vzorem intelektuální spolupráce mezi národy. $Z$ tohoto důvodu byla účast sociologických společností jako ŽSS a MSS tak důležitá. Chalupný tuto skutečnost vyložil ve své zprávě v $S R$ při 10. sjezdu MSÚ v Ženevě v říinu 1930:

„[...] hlavní základnou Institutu pro budoucnost se stávají sociologické společnosti. Jako první byla přijata Société de sociologie v Ženevě, jako druhá Masarykova sociologická společnost

10 V dopise z 25. 1. 1926 Duprat děkuje Chalupnému za jeho zaslané publikace a doufá, že se ještě jednou setkají. Znovu se setkali zřejmě v říjnu 1927 (dopis Duprata Chalupnému z 25. 1. 1926, koncept dopisu Chalupného Dupratovi z 27. 9. 1927, Literární archiv Památníku národního písemnictví, dále jako LA PNP, f. Chalupný Emanuel).

11 Jeho bývalý kolega a dlouhodobý přítel Rudolf Teltšík pracoval na Mezinárodním úřadu práce od r. 1920 do r. 1931 v Ženevě. Teltšík se rychle stal zprostředkovatelem některých korespondencí mezi Chalupným a Dupratem (koncept dopisu Chalupného Dupratovi z 27. 9. 1927, dopis Duprata Teltšíkovi z 3. 8. 1930, LA PNP, f. Chalupný Emanuel).

12 Dopis Duprata Chalupnému z 8. 10. 1927, LA PNP, f. Chalupný Emanuel. Vlastní překlad z francouzštiny. 
v Praze. Jiné národy, na sjezdu zastoupené, na ten čas nemohly svých sociologických společností přihlásit bud' proto, že jich dosud nemají, nebo že organizační formality to nedovolují.“ (Chalupný 1930b: 421)

Zároveň Duprat v dopise z 8. ř́ina 1927 pozval Chalupného, aby se stal členem ŽSS, a vyjádřil prosbu, jestli by sám prezident Československa Masaryk také přijal členství spolu s Richardem, Bouglém a vedoucím Mezinárodního úrúadu práce Albertem Thomasem. ${ }^{13}$

Druhý poválečný sjezd MSÚ v Ženevě v r. 1930 byl ve skutečnosti prvním Dupratovým sjezdem, jehož tématem diskuse byly „Základní příčiny války a dlouhotrvající podmínky míru“. Jen sociologie mohla vyřešit poválečnou „sociální patologii“ (Duprat 1932: 311). Nezapomeňme, že toto téma bylo vybráno $\mathrm{v}$ druhé polovině 20. let v kontextu váhavých kroků ve snaze zajistit dlouhotrvající mír a bližší spolupráci v Evropě. Duprat pozval také Ferdinanda Tönniese a jiné německé členy do ŽSS a po jejich vyloučení za války (další důkaz, že ústav nebyl samostatnou mezinárodní organizací v dnešním slova smyslu, ale svázaný $\mathrm{s}$ francouzskou zahraniční politikou) byli bývalí němečtí členové navíc přijati zpět do MSÚ. ${ }^{14}$ Duprat spolupracoval zejména se Solomonem Gottfriedem a Karlem Emanem Přibramem, který pracoval ve statistické sekci Mezinárodního úradu práce od r. 1921 do r. 1928. Chalupný nemohl lépe shrnout situaci ve své zprávě o prvním ženevském sjezdu MSÚ:

„Tento sjezd znamená ukončení přechodného stavu, v němž Institut International se ocitl po smrti svého zakladatele Reného Wormsa r. 1926. Postavil se nyní na nové organizační základy a svěřil agendu rukám, od jejichž agilnosti lze se nadíti, že přivedou Institut $\mathrm{k}$ většímu rozmachu a ke skutečné spolupráci mezinárodní, zejména spolupráci Francouzůa a Němců, o jejichž získání tentokráte pořadatelé sjezdu (Société de sociologie v Ženevě) zrételně a se zdarem se vynasnažili.“ (Chalupný 1930b: 421)

Neměli bychom si ovšem představovat, že MSÚ a jeho sjezdy byly jediným předmětem zájmu Chalupného a redakčního týmu revue. Kromě informací o činnostech MSÚ, ŽSS a jiných zahraničních sociologických společností, byly od prvního vydání r. 1930 podrobně a pravidelně sledovány aktivity spojené s americkou, středoevropskou nebo „slovanskou“ sociologií. Sjezdy a činnost Sociologického institutu, rivala Wormsova MSÚ ve 20. letech, se oznamovaly také, ale pochopitelně stručněji. ${ }^{15}$ Chalupný a kruh českých sociologů, ke kterému patřil, nicméně stále dávali ve 30. letech přednost Wormsem založenému ústavu a aktivněji se účastnili dalš́ho ženevského sjezdu r. 1933. Sjezd se zaměřil na téma „sociologické prognostiky“ a konal se v prrítomnosti zastupitele MSS Emanuela Chalupného, Jaroslava Křemena, který později, od r. 1931, stanul v čele Akademického oboru MSS, jakož i kulturního atašé československého velvyslanectví v Pař́ži Rudolfa Keplého (Dupratová 1934, s. 1-3). Ve své zprávě o sjezdu tohoto roku se v $S R$ Křemen zmínil, že byly prezentovány referáty Bláhy, J. L. Fischera, zesnulého Karla Šmejkala a Chalupného a Chalupný byl jmenován

13 Tamtéž.

14 Archivní fond UNESCA, i. č. DD - VII - 8 - IICI, zpráva Duprata ŽSS z 1. 3. 1929.

15 Diskuse o uspořádání mezinárodního sociologického sjezdu v Praze na počátku 20. let tímto konkurenčním ústavem byly zrušeny částečně kvůli rivalitě Cosentina s Wormsem (Voráček 1999, s.116). 
viceprezidentem ročního výboru roku 1934-1935 (Křemen 1933: 396-397). V tomto ročníku se v $S R$ poprvé objevil výčet zahraničních spolupracovníků.

Chalupný a Duprat nepochybně uzavřeli profesionální spojenectví. Chalupný viděl ve spolupráci s Dupratovým projektem proměny MSÚ ve federální strukturu jasné výhody pro českou sociologii. Jako roční viceprezident MSÚ psal v r. 1935 ve zprávě z dvanáctého sjezdu ústavu v Bruselu:

„A s uspokojením můžeme říci, že právě naše ,Masarykova Sociologická společnost‘ od prvopočátku krise vzestup Institutu podporovala; r. 1930 byla vedle Sociologické společnosti v Ženevě prvou společnosti, jež se do Institutu přihlásila a byla ,inkorporována'. Proto také naše návrhy i kandidatury docházejí u presidia Institutu největši ochoty a propagace vědy československé je zde konána se zdarem." (Chalupný 1935: 385)

Nyní bylo možné českou sociologii „,vyvážet“ do mezinárodního prostoru prostřednictvím MSS. To mohlo vyrovnat domácí situaci, ve které sociologie trpěla nedostatkem financování a uznání, na něž si Chalupný neustále stěžoval. ${ }^{16}$ Dokážeme si představit, že k tomu, aby se stal předsedou této společnosti i v r. 1930, mu pravděpodobně pomohla jeho rozhodující úloha v mezinárodních úspěších MSS. Duprat nikdy nedokázal federalizovat evropskou sociologii na základě francouzsko-německého sblížení. Jako vedoucí MSÚ zůstal v relativní izolaci, než byl nahrazen Émilem Lasbaxem v r. 1937 (Rolová 2011, s. 33-35). Mezitím našel v Chalupném spolehlivějšího spojence než v jakémkoli krajanovi, a to nejen jako v kolegovi, ${ }^{17}$ ale i jako v jednom ze svých evropských důvěrníků, ${ }^{18}$ jež podporoval i opakovaně oslavoval ve své recenzi jeho vedení v MSÚ. I když sám Duprat začal vyjadřovat už v r. 1933 své zklamání nad neúspěchy Společnosti národů, jakož i nad svými osobními nezdary umožnit sociologii, aby ovlivňovala mezinárodní politiku v Ženevě (Rolová 2011, s. 33), Chalupný se o činnostech $M S U ́$ ještě vyjadřoval pozitivně.

Duprat a Richard se v SR nikdy aktivně neangažovali. Dva přeložené Richardovy články byly publikovány v r. 1930 (ve dvou částech) a v r. 1933. První článek od Duprata vydaný ve svazku 2-3 r. 1933 byl zřejmě zkrácenou přeloženou verzí příspěvku, který byl současně vydán ve dvouměsíčním svazku RIS (květen-červen) a byl věnován tématu sociologických prognóz; druhý vyšel v r. 1935. Richardovi se jako sociologovi dostalo slušného uznání a ve Francii byl v akademickém prostředí dobře etablovaný. Avšak Dupratovy publikace mohou být považovány výhradně za známku uznání institucionálního sblížení mezi MSS a MSÚ a stvrzení jejich spolupráce.

16 Chalupný neváhal i v cizině kritizovat nedostatek státní podpory sociologie v Československu. V konceptu dopisu Dupratovi z r. 1932 psal, že MSS nevyužije žádné státní podpory, i když má jméno prezidenta Masaryka ve své denominaci (koncept dopisu Chalupného Dupratovi, LA PNP, f. Chalupný Emanuel). Dokonce se zmínil o skromných podporách Československého státu i v článku publikovaném v RIS (Chalupný 1930c).

17 Ve své recenzi v $S R$ díla Daniele Essertiera o francouzských sociolozích Chalupný litoval, že Dupratovi „věnována je pozornost jen několika řádky jako mimochodem“(Chalupný 1930a: 323).

18 Duprat měl také blízké vztahy nap̌r. s rumunským sociologem Gheorghem Vlădescu-Răcoasou (Archives départementales de la Gironde, Fonds Guillaume Léonce Duprat, i. č. 4J 738, 3 dopisy Vlădescu-Răcoasy Dupratovi z 31. 1. 1934, z 26. 2. 1934 a ze 17. 9 1934). 
Nejpozději v r. 1936 byla jména Bláhy a Chalupného přidána do seznamu spolupracovníků RIS. Dříve, v r. 1934, byli Duprat a Richard spolu s Mauricem Halbwachsem, Lucienem Lévy-Bruhlem a Reném Maunierem jmenováni dopisujícími členy MSS. ${ }^{19}$ Toto vzájemné sblížení bylo příležitostně odůvodňováno poválečným řádem v Evropě a také spojenectvím Československa s francouzskou velmocí, ale taková diplomacie mezi sociology měla sloužit především oboru sociologie a jeho propagaci. Francouzští sociologové představovali pro českou sociologii v mezinárodní strategii redakčního týmu $S R$ logistickou výhodu možného exportu české sociologie do zahraničí namísto obsahového přínosu pro samotnou sociologii jako vědu v Československu. V dopise Chalupného Dupratovi z tohoto roku je explicitně zmíněno pouze zdvořilé přání další vzájemné spolupráce na rovném základě: „Dovolíme si věřit, že intimnější vědecká spolupráce s Vámi povede nejen k lepší znalosti vědecké práce československé ve vaší zemi, ale také ke konsolidaci vědeckých vztahů mezi našimi spřátelenými národy.“20

\section{„Podnětní učitelé“ a skuteční partneři: spolupráce Célestina Bouglého a Pitirima Sorokina a jejich vztahy s Bláhou}

\section{Célestin Bouglé - statusový spolupracovník}

Célestin Bouglé (1870-1940) byl jediným západním spolupracovníkem $S R$, který na první pohled neměl žádný vztah s českou sociologií mimo revui. Neexistuje žádná korespondence mezi ním a Bláhou nebo Chalupným, ${ }^{21}$ která by mohla doložit dlouhodobé partnerství nebo společné záměry a cíle, ani se téměř neúčastnil redakční aktivity $S R$. Mimochodem Bouglé se zřejmě také nepodílel na činnostech MSÚ ve 20. letech. Nepřijal pozvánku na sjezd MSÚ r. 1930 v Ženevě jako francouzský delegát MIIS.22 Nakonec se ale zúčastnil o tři roky později v r. $1933^{23}$ dalšího sjezdu konajícího se také ve švýcarském hlavním městě (Dupratová 1934: 1). Nicméně se stal členem ŽSS vedeným Dupratem (Charle 1986: 36) a v r. 1939 patřil mezi členy MSÚ. ${ }^{24}$ Spolupráce Bouglého se $S R$ ve skutečnosti odpovídala jeho širším mezinárodním závazkům na evropské scéně, mj. se ženevskými organizacemi po

19 Tamtéž, telegram Obrdlíka Dupratovi z 1. 6. 1934.

20 Tamtéž, dopis Chalupného Dupratovi z 9. 5. 1934. Vlastní překlad z francouzštiny.

21 Bouglé si př́ležitostně korespondoval s Antonínem Obrdlíkem, zejména v únoru 1934, když se Bouglé stal dopisujícím členem MSS. Bibliothèque de documentation internationale contemporaine, dále jako BDIC, Fonds Célestin Bouglé, i.č. F/A/RES/852, k. 2, korespondence 1933-1934, dopis Obrdlíka Bouglému z 4. 2. 1934 a dopis Bouglého Obrdlíkovi z 7. 2. 1934.

22 Archivní fond UNESCA, i. č. DD - VII - 8 - IICI, dopis ředitele MIIS Levinsona Bouglému z 15. 1. 1930, telegram Levinsona Bouglému z 10. 10. 1930, telegram Bouglého Levinsovi z 13. 10. 1930.

23 Seznam zahraničních spolupracovníků v $S R$ se objevil se jménem Bouglého v č. 2-3 r. 1933. Sjezd MSÚ tohoto roku se konal 16.-22. ř́jjna, zřejmě když č. 2-3 už bylo vydáno a zpráva od Křemena o sjezdu MSÚ tohoto roku byla publikována jen ve čtvrtém čísle čtvrtletníku. Zdá se proto být jasné, že oficiální spolupráce Bouglého se $S R$ nebyla domluvena po osobním setkání (např. s Chalupným) na sjezdu v Ženevě.

24 Podle seznamu členů MSÚ z r. 1939 (RIS 1939: 565). 
první světové válce, ${ }^{25}$ ale také jeho účasti na české intelektuální scéně i jeho filozofickým afinitám zejména s Bláhou. Na závěr nekrologu (1940), který byl věnován Bouglému, připomenul Bláha různé způsoby, jak nedávno zesnulý francouzský sociolog přispěl k oboru sociologie, a to jako teoretik, organizátor, pedagog i sociální reformista (Bláha 1940, s. 154).

Bouglé se podílel na Durkheimově Sociologické ročence od jejího založení v r. 1896. Durkheim si ho vysoce cenil a pomáhal mu v době jeho univerzitní dráhy. V r. 1934 bylo jeho jméno v $S R$ stále spojené s Durkheimovým odkazem. Zpráva podepsaná nejspíše Bláhovou zkratkou „B.“ (Janák 2011, s. 999) informovala, že byla obnovena Sociologická ročenka ${ }^{26}$ přerušená v r. 1925 („B.“ 1934). Bouglé je zde uveden jako jeden z Durkheimových žáků spolu s Marcelem Maussem, Mauricem Halbwachsem a Françoisem Simiandem. Bouglé však vždycky zaujímal k Durkheimovi poněkud nezávislý postoj, byl spíš jako mladší kolega než nástupce. I když měl ve Francii úspěšnou kariéru, Bouglé se brzy začal zajímat o současný vývoj německé sociologie od konce 19. století a bližší vazby mezi tamější sociologií a filozofií (Bouglé 1896, 1912). ${ }^{27}$ Intelektuální prostor, jímž byla německá filozofie a sociologie, mohl podle něj v mnoha ohledech vyvážit Durkheimův excesivní objektivismus a byl i radikálnějším, než byl později Bláha (i třeba Richard, který se před první světovou válkou začínal názorově distancovat od Durkheima) při přehodnocování Durkheimova odkazu. Přesně jako Bláha (Janák 2009, s. 56) věřil, že Durkheimova metoda sice na jednu stranu umožňuje sociologům zkoumat už založené hodnotové systémy jako samostatné společenské jevy, ale na druhou stranu jen metoda introspekce mohla vyložit jejich vytvoření (Gülich 1990, s. 61; Janák 2009, s. 96-97). Durkheimův český student Bláha nám ve svém Bouglému věnovaném nekrologu ukazuje, že pozorně sledoval práci svého francouzského spolupracovníka, kolegy a „podnětného učitele [revue] v mnohých otázkách“ (Bláha 1940: 154). Jistě si byl také dobře vědom některých jejich afinit jako třeba v postojích $\mathrm{k}$ Durkheimovi anebo ke společenské angažovanosti. ${ }^{28}$

Od začátku 20. let se Bouglé stal součástí česko-francouzské intelektuální sítě, ${ }^{29}$ která se dále rozvinula hned po první světové válce díky samostatnosti Československa i jeho

25 Bouglé byl aktivní v MIIS a zúčastnil se sjezdu v Miláně v r. 1932, a díky svému přátelství s Albertem Thomasem uspořádal stáže v Mezinárodním úřadu práce v Ženevě pro studenty ze sociologických oborů francouzských univerzit (Dhermy-Mairalová 2017: 39-40). Od r. 1911 do r. 1927 byl také místopředsedou Ligy pro lidská práva a podílel se na založení a federalizace lig v Anglii nebo v Německu po první světové válce.

26 SR navíc byla strukturována ,po vzoru Durkheimovy Sociologické ročenky“ (Janák 2009: 56).

27 Bouglé studoval v Německu v r. 1893 a tam se seznámil s Georgem Simmlem, se kterým pokračoval v korespondenci i v první dekádě 20. století. Začala tak Bouglého spolupráce s RIS prostřednictvím překladů článků publikovaných Simmlem ve Wormsově revui v tomto období (Gülich 1990: 64-71).

28 K tomu se Bouglé zkoušel opakovaně prosadit na politické scéně mezi r. 1901 a 1924, ale podobně jako Bláha a Chalupný neúspěšně (Naquet 2017: 23-24).

29 Podle Emanuela Naqueta se později Bouglé také podílel na založení čsl. Ligy lidských prav (Naquet 2017: 22). Navíc byl Bouglé v korespondenčním styku s československým velvyslancem v Pařiži Štefanem Osuským, kterého oslovoval jako „Váženého ministra a př́tele“. Československé velvyslanectví navrhlo, aby byl přijat český student na École normale supérieure v Paříži, kterou Bouglé 
spojenectví s Francií, konkrétněji prostřednictvím jeho prátelství s Danielem Essertierem. ${ }^{30}$ Později, v r. 1936, publikoval několik článků po zvolení Beneše československým prezidentem $^{31}$ včetně článku v němčině v mimořádném čísle novin Der Prager Presse věnovaném Masarykovi a Benešovi, jenž byl nadepsaný „Československý realismus a demokratický ideál“" (Bouglé 1936c). Vedle F. X. Šaldy, J. L. Fischera, Bláhy a dvou britských spojenců Masaryka a Beneše z války Henryho Wickam-Steeda a Roberta Cecila byl Bouglé jediným francouzským přispěvatelem mimořádného čísla. V r. 1938 ještě v jiném mimořádném čísle československého časopisu $(S R)$ věnovaném Mnichovským dohodám Bouglé dále ukazuje určitou znalost intelektuální scény v českých zemích od konce 19. století. Tyto př́íklady ovšem naznačují, že Bouglé zréejmě považoval svou čestnou spolupráci se $S R$ spíše za součást ,geostrategie“ sblížení se se spřátelenou středoevropskou zemí jako celkem než jako profesionální partnerství se samostatnou vědeckou revuí zaměřenou na vzájemnou výměnu sociologické odbornosti. Stejně v opačném směru jméno Bouglého v seznamu zahraničních spolupracovníků znamenalo především symbolický prínos pro revui. Po jeho jediném článku v prvním čísle v r. 1930 nebyly žádné další Bouglého př́spěvky v $S R$ publikovány. ${ }^{32}$ Jeho činnost však byla sledována po celou dobu 30. let. Kromě Bouglého účasti na obnovení Sociologické ročenky (nyní Les annales sociologiques) v r. 1934 revue také pojednávala o jeho úloze při založení Ústavu vědeckého studia hospodářských a sociálních jevů (Institut scientifique des recherches économiques et sociales) v r. 1935 (,Z.“ 1935) a později při založení Centra pro sociální dokumentaci (Centre de documentation sociale, CDS) v r. 1936 (Moudrý 1936). Oficiální misí $S R$ bylo pravidelné předávání těchto zpráv z ciziny. $S R$ chtěla i nadále podporovat institucionalizaci sociologie i v cizině, což pomohlo podobnému úsilí doma, a to tím, že sledovala informace ohledně Bouglého činnosti jako zahraničního spolupracovníka revue (navíc oficiálně od r. 1933).

Bouglé je francouzským sociologem spolupracujícím se $S R$, který se Bláhovi nejvíce podobal, i když se oba sociologové nijak zvláště neprátelili. Předně si byli podobni na metodologické úrovni díky vzdělání ve filozofii a také díky stopám, jež zanechala německá sociologie a současná filozofie na intelektuálním vývoji a dráze obou sociologů (Janák 2009, s. 57) jako protiváhu k Durkheimově reifikaci nebo zhmotnění. Za druhé se podobali i na úrovni organizační, protože oba sociologové spolu s Dupratem neustále prosazovali propagaci sociologie

v té době řídil. BDIC, Fonds Célestin Bouglé, i. č. F/A/RES/852, k. 2, korespondence 1933-1934, dopis Bouglého Osuskému z 3.7.1934.

30 Daniel Essertier (1888-1931), na jehož dílo napsal Chalupný v $S R$ recenzi, což už jsme zmínili (viz pozn. 17), byl profesorem na Institut français de Prague a vedoucím Revue française de Prague ve 20. letech. Objevil se také na seznamu náhradníků MSÚ v r. 1928. Bouglé byl pozván jako delegát Kongresu sdružení pro Společnost národů, aby přednesl př́spěvek o sociologii a filozofii na sjezdu Jednoty filosofické v Praze v r. 1922. Stal se při této př́ležitosti jedním z čestných členů, a to o rok později než Essertier (Charle 1986: 36; Revue française de Prague 1922: 111).

31 Bouglé se tohoto roku ve Francii zúčastnil slavnosti na počest Masaryka (Bouglé 1936a). Kromě svého článku v Der Prager Press napsal Bouglé také stat' o „politické filozofii prezidenta Beneše“, jež byla publikovaná francouzsky v L'Europe centrale (Bouglé 1936b).

32 „O rodině a syndikátu“ byl překlad jeho přednášky „De la famille au syndicat“ v řadě konferencí Francouzské ligy pro mravní vzdělání, která byla publikována stejný rok ve Francii (Bouglé 1930). 
mezi širší veřejnost, stejně jako se tak dělo v akademickém světě, např. pomocí organizací jako Dupratův Dům lidu (Maison du peuple), Bouglého CDS a veřejných přednášek MSS nebo rozhlasových přednášek Bláhy. Propagace a institucionalizace měly být doprovázené mezinárodní kooperací a tito sociologové rovněž věřili tomu, co napsal tehdejší prezident MSÚ Maunier ve svém příspěvku publikovaném v mimořádném čísle $S R$ a věnovaném Mnichovským dohodám:

„[Úloha znalce] je nejen toužit po tom vzdáleném dni - pokud vůbec přijde - kdy by se mohla založit Pozitivní politika [ve francouzštině „Politique positive“, zdůrazněno autorem], kde vláda by byla dílem rozumu, kde šílení by byli léčeni, lidsky, nejlepšími doktory (ale mezi čtyřmi stěnami) ${ }^{33}$ Ta úloha je především rozdat, přes její učení, nejlepší znalost a vůli, které je připraví, pokud dojde chvíle.“ (Maunier 1938: 336)

Dalekosáhlý cíl, aby byla nastolena „pozitivní“ (pozitivistická) politika, se v jednotlivých zemích v tomto období projevoval různě, přičemž nejčastější byl ve Francii. Je možné zde jen připomenout, že angažovanost a mezinárodní aktivismus Bouglého nebo Duprata nebyly ve francouzském intelektuálním nebo akademickém světě tak výjimečné. Duprat ve své zemi jistě zůstal poměrně izolován, ale angažovanost akademicky dobře ukotvených francouzských sociologů jako Bouglého byla podobná angažovanosti Bláhy. Nicméně Bouglé, stejně jako Duprat, vyjádřil určitý skepticismus už v r. 1930 vzhledem ke schopnosti ženevských organizací, aby „sociologicky uspořádaly mír““ (Dhermy-Mairalová 2017: 41).

\section{Pitirim Sorokin: nejcennější zahraniční spolupracovník}

Nemůžěeme zde šířeji pojednávat o př́nosu, jejž měla americká sociologie od r. 1930 v $S R$ např́íklad v doméně sociologie venkova. Musíme však připomenout, že tento klad zřetelně vysvětluje významnou úlohu C. W. Haseka a především Josefa Roučka od r. 1933 (Janák 2011, s. 998-1002; Nešpor 2007, s. 53) a jejich začlenění se do seznamu zahraničních spolupracovníků. Vyř̌šili složitou situaci tím, že převzali úkol, kterým se do té doby zabýval Bláha a jeho původní „,americký tým“ ve složení Antonín Obrdlík a Bruno Zwicker. Tímto úkolem bylo poskytnout dostatečný počet recenzí amerických publikací a sbírat informace týkající se americké sociologie. Bláha měl před sebou vskutku důležitý problém. Většina publikací, které se nejen $\mathrm{k}$ sociologii hlásily nebo o ní spekulovaly, ale současně ji takříkajíc „praktikovaly“ v konkrétních př́padových studiích, byla ze Spojených států. V r. 1930 recenzoval původní „americký“ tým (Bláha, Obrdlík a Zwicker) celkem 13 ze 17 článků pojednávajících o 27 nepřeložených dílech v angličtině (24 amerických, 3 britské). ${ }^{34} \mathrm{~V}$ r. 1931 bylo stejným týmem (Bláhou, Obrdlíkem a Zwickerem) recenzováno jen 5 nepřeložených děl z angličtiny

33 Maunier se paradoxně za německé okupace ve Francii kompromitoval a v Dupratově poválečném dopisu Chalupnému je popsán jako kolaborant (dopis Duprata Chalupnému z 13. 5. 1946, LA PNP, f. Chalupný Emanuel).

34 Bláha napsal alespoň 7 recenzí, z nichž v každé zmínil jedno americké dílo, Obrdlík 3 recenze, kdy pojednával o 7 amerických dílech, a Zwicker napsal 3 recenze na jedno anglické a 3 americká díla. Navíc se neidentifikovaný recenzent „K“ zabýval 6 díly Sorokina v mimořádné sekci 
oproti 10 dílům přeloženým do češtiny, slovenštiny, němčiny a francouzštiny různými recenzenty. ${ }^{35}$ Bláha tudíž potřeboval recenzenty prímo na místě v USA s dost dobrými jazykovými schopnostmi, aby zpracovali tuto masu sociologické produkce ve Spojených státech. Hasek a především Rouček byli schopni tuto úlohu splnit v r. 1933.

Redakční tým v čele $\mathrm{s}$ Bláhou však usiloval o co nejbližší spolupráci s Pitirimem Sorokinem (1889-1968) i před vydáním prvního čísla revue v r. 1930. Bouglé publikoval svůj jediný článek v r. 1930 zřejmě kvůli své obecnější angažovanosti v evropské intelektuální kooperaci. Sorokin měl ale hlubší a osobnější vazby se samotným Československem, ${ }^{36}$ nejen s jeho předními politickými osobnostmi, jako byli Beneš a Masaryk, kterého znal od r. 1917 z Ruska a se kterým si dopisoval ještě ve 20 . letech, ${ }^{37}$ ale i s českými sociology jako Bláhou a Chalupným. Bližší Sorokinova spolupráce s budoucími vedoucími MSS a SR od r. 1922 byla tudíž př́mým důsledkem spíše těchto osobních vztahů (Voráček 1999, s. 117) než jeho účasti v MSÚ. O spolupráci se Sorokinem však měl zájem také Duprat, jenž sám pozoroval vývoj sociologie v USA a patřil k těm evropským sociologům, kteř́ si uvědomovali finanční a logistické potíže sužující vývoj sociologie v Evropě. ${ }^{88}$ I když se Sorokin stal členem MSÚ nejpozději v r. 1928, byl úžeji zapojený v činnostech ústavu teprve po r. 1934.

Sorokinovi a jeho práci se dostávalo zvláštní pozornosti v $S R^{39}$ zejména v r. 1930. Za to mohla i skutečnost, že byl aktivnější než kdokoli z francouzských spolupracovníkủ. Poskytl celkem „pět textů založených na empirickém výzkumu“ (Janák 2011: 1002), jakož i anglicky psanou recenzi Obrdlíkova díla Povolání a veřejné blaho (Sorokin 1938). V prvním vydání revue bylo recenzováno osm jeho vlastních děl a šest $\mathrm{z}$ nich $\mathrm{v}$ už zmíněné mimořádné sekci, která byla nadepsána „Z drobnějších prací Pitirima A. Sorokina“. Tato díla nebyla vybrána jen tak při prvopočáteční redakční práci revue, ale jejich zpracování bylo výsledkem Bláhovy a Sorokinovy

„Z drobnějších prací Pitirima A. Sorokina“. (Pravděpodobně Bláha, který nechtěl, aby to vypadalo, že revue je jeho osobním podnikem. Nicméně se jedná pouze o hypotézu.).

35 To by bylo dalším důkazem toho, že Bláha měl potíže zajistit v krátké době (mezi r. 1930 a 1931) přiliv současných amerických publikací. Některá americká nakladatelství, jejichž knihy byly recenzovány v $S R$ na počátku 30. let, jako byl např. McGraw and Hill nebo The Century company, měla pobočky ve Velké Británii, zřejmě aby usnadnila př́stup k evropskému trhu.

36 Sorokin byl jedním z ruských exulantů spolu s Georgesem Gurvitchem a Romanem Jakobsonem, který našel „pohostinné útočiště“ (Voráček 1999: 117) v Československu (Skovajsa a Balon 2017, s. 19), jakož i Viktor Černov, jenž publikoval článek v revui v r. 1933. Pro podrobnější informace o pobytu Sorokina v Československu i jeho nepř́mé úloze při založení MSS je třeba zmínit výše uvedený článek od Emila Voráčka (Voráček 1999), příspěvek Miloslava Petruska (Petrusek 2013) i Sorokinovu autobiografii (Sorokin 1963).

37 MÚA AV, f. T. G. Masaryk, k. 709, i. č. KOR-II-53-1925 Sorokin, Sorokinův dopis rusky Masarykovi z 12. 3. 1925.

38 Soukromé americké nadace ve 30. letech př́mo podporovaly evropské vědecké podniky, i po velké krizi r. 1929, včetně těch ve Francii. Např. Bouglého CDS bylo financováno Rockerfellerovou nadací (Dhermy-Mairalová 2017, s. 35). V r. 1931 Antonín Uhlír recenzoval Bouglého přednášku publikovanou Carnegieho dotací pro mezinárodní mír (Uhlír 1931: 353).

39 I kariéra Sorokina byla pozorně sledována v $S R$, jako třeba jeho nominace na profesuru sociologie na Harvardu, aby tam od r. 1931 vedl nově založenou sociologickou fakultu (Zwicker 1931: 130; Sociologická revue 1931: 282). 
spolupráce od konce 20. let. Spolupracovali spolu i tak, že si vzájemně zasílali názory na své práce. Již v r. 1928 Sorokin zaslal Bláhovi svi̊j Contemporary Social Theories a prosil ho o recenzi, ${ }^{40}$ a to o dva roky dř́ve, než Bláha toto dílo veřejně recenzoval v $S R$. Později tohoto roku Sorokin žádal Bláhu, aby mu zaslal svou studii Sociologie sedláka a dělníka publikovanou v r. $1925 .{ }^{41}$ Jedna z kapitol Bláhovy knihy byla později publikována v Sorokinově díle $A$ System and Source Work in Rural Sociology, a tato mezinárodní spolupráce byla inzerována v SR jako samostatná zpráva (Zwicker 1930b). Koneckonců, tyto osobní vztahy a výměny děl přes národní hranice překračují dnes také doménu anekdot. Pomohly, aby se tvořily profesionální aliance, a někdy vedly ke skutečné spolupráci (napřr. Dupratova předmluva k Chalupného dílu a Bláhova kapitola v Sorokinově publikaci) a usnadnily inzerování cizích děl v časopisech jako $S R$. Ve 30. letech byly tedy stále ještě nezbytným nositelem toho, co nyní nazýváme internacionalizací sociologie. Zatímco Chalupný se přes své spojenectví s Dupratem zabýval logistickou částí tzv. mezinárodní strategie redakčního týmu $S R$ založené na rapprochement s francouzskými sociology a mezinárodními ústavy, které vedli doma nebo v Ženevě, jako byl MSÚ, Bláha věnoval svou energii tomu, aby se aktuální americký výzkum dostal na stránky revue. I když Bláha jistě měl intelektuální a filozofické afinity s Bouglém, jeho partnerství se Sorokinem bylo konkrétnější. ${ }^{42}$ Proto tento druhý tandem spiše než tandem Bláha-Bouglé můžeme pririrovnat k tandemu Chalupný-Duprat.

V r. 1934 byl Sorokin jmenován dopisujícím členem MSS (Voráček 1999, s. 117), jakož i viceprezidentem ročního výboru MSÚ 1935-1936, a to o rok později než Chalupný (Obrdlík 1934: 232). Během přípravy dalšího sjezdu, který se měl konat v roce 1935 v Bruselu, si přímo dopisoval s Dupratem. Sorokin se sjezdu účastnil osobně spolu s dalším americkým sociologem Charlesem Elwoodem ${ }^{43}$ a českými sociology Chalupným a Janem Mertlem (Chalupný 1935, s. 385). Sorokin a Elwood se pozorně zajímali o vývoj sociologie v Evropě, což bylo v př́padě Elwooda předmětem Obrdlíkova článku v $S R$,Americké hlasy o evropské sociologii“ (Obrdlík 1930). I když Elwood byl dost kritický k situaci v Evropě včetně Francie (Obrdlík 1930: 107-108), ,označil Ženevu [kde učil Duprat] za jedno z nejlepších studijních center pro amerického sociologa, chtějícího studovati v Evropě“ (Zwicker 1930a: 191). Americká sociologie byla nejen daleko před svým evropským protějškem, co se týče kvality a množství empirické výzkumné produkce, ale američtí sociologové se nyní stali i referenčními průvodci, kteří v oboru sociologie hodnotili evropské univerzity. A i nadále zvyšovali prestiž sjezdů MSÚ už jen svou pouhou prítomností (Chalupný 1935, s. 385). Bláha nebyl prítomen částečně kvưli povinnostem a zdravotním problémům ani v Bruselu, ani na dvou předcházejících sjezdech MSÚ v Ženevě. Jeho jméno původně nebylo mezi třemi viceprezidenty ročního výboru 19351936 (Obrdlík 1934, s. 232). O rok později byl po Elwoodovi jmenován prezidentem Sorokin (1936-1937), pravděpodobně mj. jako známka uznání. Bláha byl nakonec jmenován viceprezidentem r. 1935-1936 (Chalupný 1935, s. 385). A to i navzdory faktu, že Bláha nebyl osobně

\footnotetext{
40 MÚA AV, f. I. A. Bláha, k. 2, i. č. 188, Sorokinův dopis anglicky Bláhovi z 20. 1. 1928.

41 Tamtéž, z 1.3. 1928.

42 Bláha zřejmě upřednostňoval své partnerství se Sorokinem před svým vtahem s Bouglém. Se Sorokinem korespondoval pravidelně a přímo, kdežto korespondencí s Bouglém se zabýval Bláhův zástupce Antonín Obrdlík jménem SR i MSS (viz pozn. 21).

43 Sám Elwood byl prezidentem ročního výboru 1935-1936.
} 
př́tomen v Bruselu, zřejmě to bylo jako uznání jeho úsilí a př́nosu ku prospěchu sociologie. Jeho zásluhou se Sorokin, který se zatím stal špičkou dobové americké sociologie mj. jako ředitel katedry sociologie na Harvardu, aktivně podílel na redakční práci $S R$. Bylo to i díky tomu, že se jejich přátelství z dob, kdy Sorokin v Československu na počátku 20. let pobýval jako ruský exulant, proměnilo v profesionální partnerství, které v letech třicátých ve střední Evropě významně napomáhalo zviditelnění americké sociologické práce.

\section{Závěr}

Redakční tým Sociologické revue si uvědomoval nezbytnost a př́nos zahraniční spolupráce, nejen pro $S R$, ale i pro budoucnost české sociologie jako celku. V průběhu prvních let působení vykrystalizovalo v rámci mezinárodní strategie vedení $S R$ několik typů zahraniční spolupráce, která dosáhla takového stupně, že od roku 1933 revue trvale uveřejňovala seznam svých zahraničních spolupracovníků.

Rok 1933 byl v mnoha ohledech vrcholem mezinárodní viditelnosti MSS i české sociologie v MSÚ a tato spolupráce na institucionálním základě měla své širší souvislosti i nad rámec činnosti revue. Francouzskými kolegy vedený MSÚ byl už od doby svého založení na konci 19. století nejvýznamnějším mezinárodním fórem pro propagaci české sociologické tvorby. Mít Duprata a Richarda v seznamu zahraničních spolupracovníků s sebou neslo určitou deklaraci institucionálního spojenectví MSS s MSÚ, ze kterého plynula i možnost prezentace české sociologické práce $\mathrm{v}$ zahraničí.

V meziválečné době si stále více evropských sociologů uvědomovalo kvalitu i průkopnický charakter americké sociologické práce. Participativní spolupráce Haseka a Roučka, která se naopak omezovala na hojné autorské př́spěvky v českém časopise, tudíž měla zajistit pravidelnou informovanost českých sociologů o nejnovejjších pracích z Ameriky, která mohla inspirovat podobné rozsáhlé projekty v Evropě a časem snad i spolupodnítit evropské vlády nebo univerzity, aby je lépe financovaly.

Sociologie byla nicméně stále poměrně nová i sporná věda. Podpora akademicky dobře ukotvených celebrit (Bouglé, Sorokin) v tomto oboru ze sociologických „velmocí“ pomáhala legitimizovat sociologii v Československu a $S R$ v rámci sociologické obce a představovala pro ni symbolický přinos. Hlavním trumfem mezinárodní strategie Bláhy a redakčního týmu $S R$ ovšem bylo využívání existujících kontaktů s prestižním harvardským ředitelem Sorokinem, který byl ochoten osobně se připojit k projektům svých československých kolegů, s nimiž spolupracoval od počátku 20. let. V tomto smyslu byl Sorokin nejstarším, nejsolidnějším a bezpochyby nejefektivnějším zahraničním spojencem Bláhova profesionálního kruhu, ba i české sociologie jako celku ve 30 . letech.

Na první pohled se může zdát, že francouzští sociologové hráli méně významnou úlohu a že i jejich postoj byl vůči středoevropské revui lhostejnější. Doopravdy tomu bylo tak, že charakter a míra spolupráce se $S R$ byla udávána potřebami revue. Odrážela se především ve strategii Bláhy a Chalupného, kteří využívali každého spolupracovníka ze zahraničí pro specifické cíle. Jejich mezinárodní strategie měla rozvíjet především jejich vlastní, tj. původní českou sociologii, což bylo také hlavním cílem internacionalizace české sociologie před druhou světovou válkou realizovaným vedením hlavního českého sociologického časopisu. 


\section{Literatura}

„B“. 1934. „Annales sociologiques.“ Sociologická revue 5(4): 394.

BENEŠ, Edvard. 1930. „Dopis ministra Edvarda Beneše.“ Sociologická revue 1(1-2): 3-5.

BLÁHA, I. Arnošt. 1921. La sociologie tchèque contemporaine. Paris: M. Giard.

BLÁHA, I. Arnošt. 1940. „Célestin Bouglé †.“ Sociologická revue 11(1-2 ): 150-154.

BOUGLÉ, Célestin. 1896. Les sciences sociales en Allemagne. Les méthodes actuelles. Paris: G. Baillière.

BOUGLÉ, Célestin. 1912. Les sciences sociales en Allemagne. Le conflit des méthodes. Paris: F. Alcan.

BOUGLÉ, Célestin. 1930. „De la famille au syndicat.“ Pp. 81-90 in Belot, G. Les problèmes de la famille et le féminisme. Conférences faites à la Ligue française d'éducation morale. Paris: F. Nathan.

BOUGLÉ, Célestin. 1936a. „Discours.“ Pp. 21-25 in Hommage au président Masaryk : chef et serviteur de la liberté démocratique. Dijon: Imp. Darantière.

BOUGLÉ, Célestin. 1936b. „La philosophie politique du président Beneš.“ L'Europe centrale 47: 749-759.

BOUGLÉ, Célestin. 1936c. „Der tschechoslovakische Realismus und das demokratische Ideal.“ „Zwei Präsidenten “ - Sonderbeilage der „Prager Presse“ 7. III. 1936: 4-5.

DHERMÝ-MAIRALOVÁ, Marine. 2017. ,„Faire vibrer les cœurs à l'unisson“. Célestin Bouglé et Albert Thomas, entre science et action (1920-1932).“Les Études sociales 165: 31-49.

DUPRAT, Guillaume Léonce. 1932. „Conclusion. L'organisation internationale de la paix.“ Annales de l'Institut international de sociologie 16: 311-315.

DUPRATOVÁ, Jeanne. 1934. „XI ${ }^{\mathrm{e}}$ congrès tenu à Genève du 16 au 22 octobre 1933. Compte rendu.“ Archives de sociologie 2(1): 1-46.

GÜLICH, Christian. 1990. „Célestin Bouglé et Georg Simmel. Une correspondance franco-allemande en sociologie.“ Mil neuf cent 8: 59-72.

CHALUPNÝ, Emanuel. 1930a. „Daniel Essertier: Philosophes et savants français du XX. siècle. Extraits et notices. V. La sociologie.“ Sociologická revue 1(3-4): 323-324.

CHALUPNÝ, Emanuel. 1930b. „X. sjezd Institutu International de sociologie v Ženevě 12.- 16. ř́ijna 1930.“ Sociologická revue 1(3-4): 421-422.

CHALUPNÝ, Emanuel („Chalappy“ [sic]). 1930c. „La sociologie tchécoslovaque pendant ces dernières dix années." Revue internationale de sociologie 38(7-8): 411.

CHALUPNÝ, Emanuel. 1935. „XII. kongres Mezinárodního ústavu sociologického.“ Sociologická revue 6(3-4): 383-387.

CHARLE, Christophe. 1986. „Bouglé (Charles, Alfred, Célestin).“ Publications de l'Institut national de recherche pédagogique 2(2): 35-37.

JANÁK, Dušan. 2009. Hodnoty a hodnocení v sociologii Inocence Arnošta Bláhy. Brno: FSS MU.

JANÁK, Dušan. 2011. „Autorská a tematická struktura Sociologické revue. Příspěvek k sociologickému rozboru dějin české sociologie." Czech Sociological Review/Sociologický časopis 47(5): 991-1016.

JANÁK, Dušan. 2018. Klasická sociologie ve střední Evropě: Mezi centrem a periferií. Praha: Sociologické nakladatelství.

KŘEMEN, Jaroslav. 1933. „XI. kongres Mezinárodního sociologického ústavu v Ženevě.“ Sociologická revue 4(4): 396-397.

MASARYK, Garrigue Tomáš. 1898. „La crise scientifique et philosophique du marxisme contemporain.“ Revue internationale de sociologie 6(7): 511-528.

MAUNIER, René. 1938. (Dopis vytištěný v Soc. revui). Sociologická revue 9(3-4): 334-336.

MOUDRÝ, Miroslav. 1936. „Sociologický výzkum ve Francii.“ Sociologická revue 7(3-4): 407-408.

NAQUET, Emmanuel. 2017. „Un républicain en droits de 1'Homme : le cas de Célestin Bouglé.“ Les Études sociales 165: 7- 30.

NEŠPOR, R. Zdeněk. 2007. „5. Sociologické časopisy.“ Institucionální zázemí české sociologie pred nástupem marxismu. Sociologické studie/ Sociological Studies 7(2): 48-59. 
OBRDLÍK, Antonín. 1930. „Americké hlasy o evropské sociologii.“ Sociologická revue 1(1-2): 107-113.

OBRDLÍK, Antonín. 1931. „Emanuel Chalupný: Précis d'un système de sociologie.“ Sociologická revue 2(1): 60-61.

OBRDLÍK, Antonín. 1932. „Mezinárodní sociologický sjezd v Ženevě 1933.“ Sociologická revue 3(3-4): 394-395.

OBRDLÍK, Antonín. 1934. „Institut international de sociologie.“ Sociologická revue 5(1-3): 231-232.

PETRUSEK, Miloslav. 2013. „Sorokin Pitirim Alexandrovič.“ Pp. 357-361 in Zdeněk R. NEŠPOR a kol. (eds.). Slovník českých sociologů. Praha: Academia.

REVUE FRANÇAISE DE PRAGUE 1(1): 111-112. 1922 „Sociologie et philosophie. Revue critique et documentaire."

REVUE INTERNATIONALE DE SOCIOLOGIE. 1939. „Liste des membres de 1'Institut international de sociologie.“ RIS 1939: 565-581.

ROLOVÁ, Cécile. 2011. „Guillaume-Léonce Duprat (1872-1956), l'Institut international de sociologie et l'Allemagne dans l'entre-deux-guerres.“ Lendemains 36(141): 18-42.

ROLOVÁ, Cécile. 2015. „La Société de sociologie de Paris : un continent méconnu. (1895-1952).“Les Études sociales 161-162: 119-173.

SKOVAJSA, Marek a Jan BALON. 2017. Sociology in the Czech Republic. Between East and West. London: Palgrave and MacMillan.

SOCIOLOGICKÁ REVUE 2(2): 282-283. 1931. „Z harvardské univerzity“.

SOROKIN, Pitirim. 1938. „Dr. Antonín Obrdlík: Povolání a veřejné blaho.“ Sociologická revue 9(1-2): $227-228$.

SOROKIN, Pitirim. 1963. A Long Journey. The Autobiography of Pitirim Sorokin. Lanham, Md: Rowman and Littlefield.

UHLÍŘ, Antonín. 1931. „Národ, národnost a národní menšina z hlediska sociologického a filozofického. Podle C. Bouglé.“ Sociologická revue 2(3): 352-356.

VORÁČEK, Emil. 1999. „Emanuel Chalupný, problémy rozvoje sociologie v Československu 20. let a vznik Masarykovy sociologické společnosti.“Pp. 107-130 in J. ZUMR (ed.). Emanuel Chalupný, česká kultura, česká sociologie a Tábor. Praha: Filosofia.

„Z.“1935. „Institut scientifique de recherches économiques et sociales.“ Sociologická revue 6(1-2): 223. ZWICKER, Bruno. 1930a. „Z činnosti sociologických společností v cizině.“ Sociologická revue 1(1-2): 191. ZWICKER, Bruno. 1930b. „A system and source work in rural sociology.“ Sociologická revue 1(1-2): 193. ZWICKER, Bruno. 1931. „Prof. Pitirim A. Sorokin.“ Sociologická revue 2(1): 130-132.

\section{Archivní fondy}

Archivní fond UNESCA, Paříž. Dossier DD - VII - 8, IICI - Congrès de sociologie (Francie).

Archivní fond I. A. Bláhy, Masarykův ústav a archiv AV ČR Praha.

Archivní fond E. Beneše, Masarykův ústav a archiv AV ČR Praha.

Archivní fond T. G. Masaryka, Masarykův ústav a archiv AV ČR Praha.

Archivní fond Célestina Bouglého (korespondence 1933-1934), Bibliothèque de documentation internationale contemporaine, Nanterre (Francie).

Archivní fond G. L. Duprata, Archives départementales de la Gironde (Francie).

Osobní pozůstalost E. Chalupného, Památník národního písemnictví, Praha a Litoměřice.

\section{Autor}

Christopher Montel je francouzský student doktorských studií (Soudobé evropské dějiny) na Fakultě humanitních studií na Karlově univerzitě v Praze.

Kontakt: montelcgz@yahoo.com 